\title{
Adam Alston*
}

\section{Making Mistakes in Immersive Theatre: Spectatorship and Errant Immersion}

DOI 10.1515/jcde-2016-0006

\begin{abstract}
Immersive theatre makers often go to great lengths to configure and control each aspect and detail of an immersive theatre environment; but what happens when an audience member breaches its borders, while remaining unaware of their transgression? This article explores how the coherence of an immersive theatre aesthetic is not necessarily threatened by acts of 'errant immersion', in which the audience strays off an immersive map designed and intended for them. The errantly immersed spectator accepts but accidentally takes too far an invitation to explore, perceiving and folding a range of aesthetic stimuli that are unintended by a designer into their immersive experience of a theatre event. Drawing on studies of immersion, failure and urban dramaturgy in recent theatre and performance discourse, and reflecting on anecdotal experiences of errant immersion in work by dreamthinkspeak and Coney, the article reflects on the creative and constitutive role played by audiences in immersive theatre aesthetics, and assesses the currency of the 'immersive theatre' neologism through an address of its core subject: the audience.
\end{abstract}

Keywords: immersive theatre, errant immersion, audience participation, mistakes, dreamthinkspeak, Coney

Several British site-responsive theatre companies formed either just before or just after the turn of the 21st century have been marshalled into an increasingly popular taxonomy as makers of immersive theatre, including dreamthinkspeak, Punchdrunk, shunt, Wildworks, and wilson+wilson (Machon passim). While theatre scholarship has identified work outside of the British and Anglo-American contexts in terms of audience immersion (Dinesh 67), and critiqued the parochial focus on largely white British theatre makers that has so far dominated immersive theatre discourse (Werry and Schmidt 470), the fact remains that the term emerged from the British theatre scene, and presents itself as a popular label for practices past and present that had previously gone by other names (environmental, site-responsive / -specific, promenade, performance installation, theatre of

*Corresponding author: Adam Alston, E-Mail: a.alston@surrey.ac.uk 
experience, and so on). Therefore, it is worth reflecting on the currency of 'immersive theatre' in contemporary British theatre, if only to clarify its terms of reference - terms that might be widened, recoded or abandoned as theatre makers from diverse contexts and demographics experiment with the possibilities of spectatorship, participation and scenography.

The origins of the immersive theatre moniker are murky, tied into histories and theorisations of virtual reality performance (McKenzie 86) and radical performance (Kershaw 194), but British theatre criticism (Gardner) and scholarship (Nield 531) in the first decade of the 21st century nonetheless played important roles in identifying a shift of emphasis in British theatre practice from a performance's relation to site, to its handling of audiences. This is not to suggest that site-responsive theatre performances were previously ignorant of audience immersion; rather, it is to suggest that immersive theatre discourse tends to focus more on the relationship of audiences to a theatre environment that surrounds them completely, on audiences' emotional and embodied responses to theatre, and on work that tends to invite a physically explorative mode of audience engagement (see, for instance, Alston, “Audience Participation” 133; Machon 22, 28, 67-68; White passim; Zaointz 407; see also Frieze 225). Site and space often appear as key themes in this discourse, but their importance tends to be secondary to the subject of immersion - which is to say, the audience.

Rather than binding globally dispersed and diverse theatre practices to British cultural imperialism, asserting 'the origins' of a term and its definition as a model to which these practices ought to conform, this article looks instead to interrogate audience immersion by divesting its core features from affiliation with any single practice, form, genre or style. To this end, I focus on the creative investment of audiences in a situation that is interpreted to be both 'immersive' and 'theatrical', and on assessing the role such investment plays in the constitution of immersive theatre aesthetics. Instead of accusing audiences, critics and scholars of being wrong when they identify diverse theatre practices as immersive theatre, I want to respect such claims and theorise how different forms and styles of theatre might produce a sense of immersion despite a lack of consistency across a definitional field that is nothing if not promiscuous. In other words, this article sets out to explore immersive theatre not so much as a practice that foregrounds space or site, for instance, as themes that rest at the centre of a theatre aesthetic, but as a tendency in contemporary theatre that posits the audience as a subject who produces a sense of immersion for themselves, perceiving and folding a range of aesthetic stimuli, or cues, into their immersive experience of a theatre event. While the positing of audiences as subjects who must produce a sense of immersion for themselves implies a grouping of practices, the onus on audience productivity also suggests a possi- 
ble reason as to why 'immersive theatre' has garnered such a wide field of applicability.

In the next section, I focus on a performance by a British theatre company that has found itself (re-)labelled as makers of immersive theatre - dreamthinkspeak's In the Beginning Was the End, which was performed in 2013 in Somerset House, an 18th-century neoclassical building in Central London, now a cultural centre, which joins onto King's College London's Strand Campus. dreamthinkspeak still identify as a site-responsive performance company, but the artistic director, Tristan Sharps, is happy to accept that terms and taxonomies will evolve around a particular body of work as promoters, critics and audiences seek out fresh ways of understanding and approaching theatre performances (Sharps; see also Machon 268-9). Nonetheless, the apparent shift of emphasis from site to audience in the discourse surrounding theatre practice (which at times rubs up against the preferred language of theatre practitioners) merits reflection if the instructiveness of immersion as a conceptual tool is to be clarified.

The section after that addresses a piece called Adventure 1 (2015 and ongoing) by Coney, a British interactive and game-based theatre collective recognised as immersive theatre makers in fairly recent theatre scholarship (Machon) and criticism (Brewis). Adventure 1 invited playing audience members to chart journeys throughout the St. Paul's area of central London in response to the guidance of a pre-recorded narrative relayed through headphones. It took place almost entirely in the open air, which is curious given Coney's labelling as immersive theatre makers, as there is little that audiences encounter that has been specifically designed as part of an immersive theatre environment. What is it that immerses audiences on a city's streets, where the boundaries of a tightly-controlled immersive theatre environment are not readily apparent or clear? I do not mean this as a rhetorical question, but rather want to take seriously the prospect of audience immersion in the open air. How is a sense of immersion produced among audiences in such work, and what can this tell us about immersive theatre aesthetics more broadly?

\section{Errant Immersion beyond Closed Doors}

In the Beginning was based on the Book of Revelation, the multidisciplinary field of mechatronics and a drawing by Leonardo da Vinci called A Cloudburst of Material Possessions (1510), which depicts innumerable human-made objects falling from the sky. It was spread throughout numerous rooms in Somerset House and King's College London, with free-roaming audiences entering a phantasmagorical world as a kind of time-travelling dreamer. Toward the start, rooms were 
cluttered with outmoded but functional measuring devices and computers, and were populated by chalk-wielding scientists and technicians; toward the end, audiences found themselves in a sci-fi world featuring robots, futuristic gadgets, technocratic engineers-cum-sales-folk and suicidal white-collar workers. The performance staged a da Vinci-inspired deluge of commodities, gadgets and gizmos, and explored their relationships to bureaucrats, technicians and machine-smashing Luddites who strove or struggled to keep pace with an oppressive technocracy.

In the performance's early phase, I found a door with a sign that read 'DO NOT ENTER'. In the context of an immersive theatre performance, a sign that reads 'DO NOT ENTER' means much the same as a sign that reads 'ENTER', so I pushed open the door. It was very dark inside, and very dusty. Scaffolding structures that stretched up toward the ceiling were just about noticeable in the gloom. The further I ventured, the darker it got. I tripped over something: a metal box that made a loud clatter as its contents spilled onto the floor. I felt around me and soon realised that the obstacle was a tool box... an actual toolbox - in an actual building site. Somerset House was at the time undergoing refurbishment and the renovators, presumably, or whoever was last in the room, had forgotten to lock the door before the performance had started, which adjoined onto a carpenter's workshop that was also meant to be out of bounds. ${ }^{1}$ So the sign that read 'DO NOT ENTER' really meant 'DO NOT ENTER'. And yet, this turned out to be a thrilling moment because of a childish excitement that accompanied accidental trespassing. After staying a moment longer, I turned back and re-entered the mapped performance space, only to find a couple of other audience members hovering outside the door before tentatively crossing the threshold into the dark beyond.

In passing through this particular door, I had done something that I was not meant to do. Several other doors could either be opened in the performance and installations could be found on the other side, or doors were locked or blocked by an usher, so I had been trained to equate unlocked doors with a license to explore and an expectation that I would be rewarded with something more to engage with. An error had occurred, but only insofar as my judgement and conduct digressed from what was intended for me to explore - an error shared with whoever forgot to lock the door. However, the Latin root of the term 'error' is of more use to an address of this particular moment: errare, which means 'to stray'

1 The layout of the performance space and its positioning within King's College London and Somerset House was clarified to me in a personal interview with Tristan Sharps (see Sharps). I am grateful for his time and generosity. 
or 'to wander'. I had strayed from an intended path as a free-roaming audience member, mis-taking the door as a threshold that was meant to be crossed. The breach of this threshold conformed to the logic of navigation invited by the performance, but transgressed the physical parameters intended by a theatre designer to define and demarcate the interior of a fictive landscape. Interestingly, though, I was not robbed of a sense of immersion after having strayed beyond an immersive boundary, at least initially; instead, I had become errantly immersed.

An errant audience member - one who strays from an intended course 'mis-takes' their environment as a designed or planned feature of an immersive world. They make mistakes, and that making is a creative process, one that relates to the condition of emancipated spectatorship proposed by Jacques Rancière in The Emancipated Spectator - albeit in a performance that builds on a physically active and involved form of audience engagement, which is a form that bears the brunt of his critique. The errantly immersed audience member plots her own path through a physically dispersed forest of things, acts and signs that are provided and that can be wandered through and at times interacted with, but they also extend the borders of this forest beyond those intended by a theatre maker.

Immersion might well be contingent on engagement with a designed aesthetic space, but physically placing the audience in a panoramic installation does not guarantee a sense of immersion among individual audiences, who may have other things on their mind - what they want for dinner, for instance, or a frustration at work that bubbles into consciousness. What is required - in this performance, at least - is commitment to a framework for audience engagement based on a physically explorative and pedestrian spectatorship, and a creative investment in the extra-ordinary. The errantly immersed audience member does not digress from either of these conditions; rather, she enhances further the commitment to creative productivity that they elicit. The errantly immersed audience's commitment to productivity both makes and breaks the performance intended by a theatre maker, while potentially maintaining - at least for a while - their own sense of aesthetic cohesion as the borders between a theatre maker's intentions and an audience's expectations are conflated.

This is what leads me to argue that a sense of immersion, while contingent on an awareness that one is meant to feel immersed, is also dependent on a process of investing in immersion as a spectator, whether or not that investment occurs in a space intended for immersion. The implications of this argument are that intention and a theatre maker's expertise, which have been pitched as defining features of immersive theatre in extant discourse (Machon 100), are not prerequisites for a sense of immersion to be aroused. Even when the audience steps off an immersive map, they are still able to bring a sense of immersion with them via a generative investment in performance. Stepping through the wrong door in 
dreamthinkspeak's In the Beginning demonstrates how audiences can feel immersed by accident, enhancing the reach of immersion by rendering it applicable to spaces that spill beyond the designed parameters of a theatre environment, provided that environmental conditions are perceived to be relevant by an audience member who expects and anticipates the furthering of an immersive experience.

It may well be that errant immersion is something that immersive theatre makers want to avoid as far as possible, and yet straying from a plotted path or expected course of action enables a generative feature of immersive theatre aesthetics to be identified and understood more readily. This feature does not relate to the risk of a represented world undoing itself by way of failure, which is a risk that haunts all theatre, as Nicholas Ridout recognises (Stage Fright 168); also, my argument is not addressing how failure promotes alternative ways of doing or making, necessarily, as Sara Jane Bailes puts it in her engaging study of the poetics of failure in contemporary performance (2-3). To the contrary, my argument is that errant immersion is mistakenly productive of a represented world, and that it highlights that which is already present within the condition of immersive theatre spectatorship - it extends and enhances, rather than forges anew, the productivity of spectatorship via an errant reading of an otherwise encouraged explorative license.

Perhaps traces of 'MISperformance', which was the theme of the 2009 Performance Studies International conference in Zagreb, can be identified in this thesis; however, errant immersion is not the result of spectatorship in performance 'misfiring' or 'misfitting', which otherwise characterise the most relevant arms of MISperformance (Feldman 1). While MISperformance is pitched by its conceptual instigators as a wide-reaching concept that continually seeks to redefine and reassess its meaning and field of applicability (Blažević 5), errant immersion does not conform to the 'wrongness' implied by the various applications of the prefix 'mis', beyond 'mis-taking' something as an intended feature of an immersive environment; rather, errant immersion complies with a logic of explorative and pedestrian spectatorship, which is antithetical to MISperformance. Even if the notion of MISperformance looks to move beyond the coupling of 'mis' and 'wrongness', it still implies some kind of failure - albeit potentially productive in outcome - or divergence from some kind of plan or blueprint (Blažević and Feldman 13). However, while the errantly immersed spectator does permeate the scenographic blueprint of immersive theatre design, she also subscribes to a more fundamental feature of immersive theatre aesthetics that builds and relies on the spectator's creative perception of the world around them, and the recognition or casting of that world as being of some kind of relevance to an immersive experience that is theirs to endure or enjoy. 
Unlike Ridout's useful identification of the 'mis-spectator', an 'in-expert' spectator who accidentally reads against the grain ("Mis-spectatorship"), errant immersion is the result of a surplus in expertise, reading too well and taking too far an invitation to get involved. Errant immersion also precludes deliberate attempts to read against the grain; as soon as an audience member goes out of their way to 'break' a performance or disengage from a creative investment in the pretence of an involving theatre scenario, then the spectator simply becomes errant, not errantly immersed, as a sense of immersion dissipates and the broken parameters of an immersive environment are revealed as just that - broken. Errant immersion is premised on making mistakes that make; rather than reading against the grain, accidentally or deliberately, the errantly immersed spectator both conforms to and exceeds the intentions of theatre makers, and escapes the aesthetic boundaries that they construct.

\section{Errant Immersion in the City}

In dreamthinkspeak's In the Beginning, the boundaries that are meant to divide an immersive world's interior and exterior are comprised of doors and walls; these are physical boundaries intended to demarcate a site for exploration and immersion, and to signal that which is out of bounds and beyond the fictive cosmos of an immersive environment in a way that may not always be clear, and that might give rise to readings that exceed the space that has been crafted or adapted by its designer. However, the boundaries that define the parameters of an immersive environment may also be defined more loosely, as they are in Coney's headphone performance Adventure 1, where the playing space for an immersive experience is superimposed onto a cityscape. The city introduces factors that elude the possibility for an "otherworldly-world" to be navigated "according to its own rules of logic”, in Josephine Machon's terms (62-63; see also Calleja 23-32), as the 'logic' of an immersive theatre performance is forced to forge some kind of pact with the uncertain and volatile happenstances that unfold on a city's streets. Therefore, it is worth reflecting on the extent to which immersive theatre can be said to exist at all outdoors, where light, sound and scenography cannot be manipulated so easily to craft the contours and detail of an immersive environment that transports audiences to an otherworldly-world. If it can, what is it that immerses audiences beyond the day-to-day immersion in the metropolis experienced by a city's inhabitants?

Adventure 1 begins with a small audience congregating outside One New Change, an office and retail centre by St. Paul's station in Central London. They are then guided on individual journeys through the surrounding streets and 
squares by a series of voicemails, text messages and tracks downloaded onto a smartphone in advance of the event, updating the now familiar territory of audio walks associated with artists and companies like Janet Cardiff and Platform by pluralising the range of possible journeys that audiences can explore. Each journey is determined by the sequence of tracks that the audience chooses to listen to. In my case, I initially headed to Paternoster Square, which is home to the London Stock Exchange, and then onto a range of corporate, commercial and misleadingly public spaces, including a nearby and unmarked Goldman Sachs office and a branch of the coffee shop chain Pret a Manger. A climactic point comes when the audience gathers on the steps of St. Paul's Cathedral, where they are asked to hatch a plan to steal a bag from an anonymous stockbroker called Mr. X. The bag is said to contain a memory stick that holds lucrative information. Our group found and then surreptitiously tailed Mr. X into a nearby bar, after which one of our comrades distracted him while another slipped the bag from between his legs and made his way outside, followed swiftly by the rest of us.

Adventure 1 sets up an 'urban dramaturgy' for its audiences to engage with, which is a notion borrowed from contemporary performance scholar Bertie Ferdman. Urban dramaturgies "identify the proliferation of both performance in cities and the performance of cities", she writes: "We can think of urban dramaturgies as vanishing mises-en-scène taking place in the global city: ephemeral live acts, be they rehearsed scenarios, improvised happenings, impromptu gatherings, organized events, festive encounters" ("Off the Grid” 17). Coney, much as Ferdman recognises in the myriad performances that unfold in the streets of New York City each year, intends an altered encounter with the city, making it seem "weird, alive, different, poetic, new” (Ferdman, “Off the Grid” 17) through commitment to a core dramaturgical premise:

[T] he possibility that stories can be told from different perspectives, that composition in a given context renders meaning through interpretation, and that imagination renders something real. 'Dramaturgy' also connotes narrative (not necessarily a linear one), which is essential in establishing what story we want to tell, for whom, and by whom. (Ferdman, "Urban Dramaturgy" 25)

Adventure 1 casts its participants as performing audiences within the performing city; it invites audiences to read the city as performance while engaging with it through performance. It imposes an urban dramaturgy as a hermeneutic process undertaken by subjects who render meaning through a critical interpretation of the city from a perspective that differs from a more quotidian script. Coney ask their audiences to navigate the city's streets as a trespasser and as a voyeur, as one who is meant to 'pass' as a pedestrian like any other, but who is also meant to differ from these others as an interloper whose interloping goes unnoticed. They 
ask their audiences to practice an urban dramaturgy that merges with the performing city, ideally imperceptibly, and to see the world around them anew but not so much through a child's eyes, as in the Benjaminian tradition; rather, to see anew the cityscape as if through the eyes of a dissident who is aware of their dissidence as a subtle, inconspicuous and ludic intervention.

The audience is therefore given a role, of sorts, that brings into tension the performing city and the urban dramaturgy of an immersive performance. Furthermore, the audience is encouraged in several of the recorded tracks to think up a plausible backstory just in case they are confronted by a member of the public or a security guard, perhaps for gazing at a landmark that does not lend itself to touristic interest for an extended period of time. Such pretence derives from accepting the performing city as an object of aesthetic reflection and as a playspace in which one participates as a performing audience who has a role to play a role that is theatrical, and that might also lead to consequences that rupture pretence if those who are not in on the game disrupt its smooth operation.

For instance, I remember watching a table of young men in the bar toward the end of the performance at the moment when the bag was stolen, one of whom made a half-hearted effort to rise and intervene, having clocked the theft. These men were nothing to do with the performance and presumably were not aware that a performance was going on. While it is perhaps disheartening that they did not intervene if they thought that a theft was actually taking place, it nonetheless made me wonder what would have happened if a member of our group had been assaulted in an attempt to retrieve the bag. The audience's playing at subversiveness and illegality would collapse into the actual intervention that the performance makes into a space that does not recognise the co-presence of an urban dramaturgy and the performing city. If the audience does end up feeling immersed within the logic of the performance's urban dramaturgy, then, it is a precarious immersion that is continually threatened by the myriad and unpredictable possibilities and contingencies of the city's inherent eventfulness.

The eventfulness of an ephemeral live act in which the audience participates and the eventfulness of the contemporary city end up layered in Adventure 1 in such a way that the audience remains at some distance - an almost Brechtian critical distance - from the world around them, which would seem to complicate the likelihood of generating a sense of immersion among the performance's audiences. However, the 'event landscape' of St. Paul's, to borrow from Gavin Kroeber - composed of a cathedral-cum-tourist-attraction, the staged environments behind each of the shop's windows, the glass facades of London's financial heart and the improvisatory hustle and bustle of pedestrian movement - is rendered engagingly and absorbingly curious. Art and the city are not so much blurred through this curious casting of the city; while Adventure 1 certainly 
participates in the daily grind of event production, it seems more apt to describe it in terms of "negotiation with the forces of authority" that have produced or endorsed a particular set of sanctioned experiences, such as those pertaining to consumerism and tourism, giving rise to "a dynamic of control and possibility" (Kroeber 39). Moreover, such a dynamic is predicated on a subversive and theatrical pretence - adopting the guise of an inconspicuous interloper - that rubs up against the event landscape of the performing city and takes on a thrilling doubleness as one's interloping character and ambiguously legal activity play off one another. Immersion in Adventure 1 builds on the familiar and quotidian environment of the cityscape and harnesses the city as a ready-made environment, but what casts this performance as 'immersive theatre' is what the performance adds to this environment, which is a surplus that can only be produced through the productive investment of audiences in a precarious pretence that overlays the event landscape of the performing city. The 'immersiveness' of Adventure 1, therefore, derives from a tension between the performing city and the urban dramaturgy of an immersive theatre performance that a participating audience member is invited to negotiate, and without whom there would be no tension.

To illustrate and unpack this line of argument, I want to turn again to an experience of errant immersion. The steps of St. Paul's Cathedral is a politically resonant space, having hosted Occupy London Stock Exchange (Occupy LSX) in 2011-12 after protestors were prevented from setting up camp in Paternoster Square. Occupy LSX, part of a well-known global protest movement, primarily targeted the volatility of contemporary capitalism in the aftermath of the 2008 global financial crisis, and an ensuing raft of austerity measures that were put into place in the UK by the Conservative-Liberal Democrat coalition government (Occupy London). It was with this context in mind that I made a mistake in Adventure 1. I was asked to seek out a telephone box opposite One New Change and to identify a sign stuck to its roof that would confirm its appropriateness. Assuming it must have been near where the performance started, I found what I thought I was meant to be looking for when I spotted a white sticker with the beginnings of the word 'Occupy' stuck to its roof - only the last letter was illegible. I was prompted by text message to call a number on arrival at the phone box, at which point the phone was meant to ring (an exciting prospect and frankly one that I have secretly wanted to experience since childhood). However, this turned out to be the wrong box, which became clear after an interminable silence. I had not followed a set of directions to get to the right phone box accurately enough - by some margin - and was meant to head to the centre's northern entrance, not its south-western side.

However, my stroll to the wrong phone box was still a rich experience that accidentally chimed with the themes of the performance's urban dramaturgy. The 
sticker on the roof and the presence of a phone box opposite One New Change, albeit the wrong one, nonetheless signalled a serendipitous discovery that could be invested in as an evocative part of the performance. While the city's event landscape inputs manifold complexities, uncertainties and precariousness into an immersive scenario that eludes controllability, I was still able to experience a sense of immersion that overlaid an aesthetic playspace on top of an urban environment, at least up until the realisation that I had strayed off the beaten track. Importantly, the performance's 'immersiveness' was cued by a framework for audience engagement devised by Coney, and was thoroughly rooted in the St. Paul's site, but only took on any real meaning and affect once an urban dramaturgy was invested in and recognised as a zone that could be inhabited by a ludic subject. This zone is mapped onto a city's streets as an invited mind-set and corporeally-rooted relation to space; it is a zone intended by Coney, but is ultimately 'of' the audience. As the journey to the wrong phone box illustrates, it is a zone that can be stretched beyond an intended playspace and that need not lose its coherence as a result.

\section{Conclusion}

Perhaps the most useful aspect of the neologism 'immersive theatre' is that it facilitates a better understanding of the audience's centrality in a range of contemporary theatre practices as a subject who may find himself imagining more than what is there, and whose creativity and productivity is enhanced as a result of immersion in an environment that invites the perception of personal significance, ownership and use. There is a risk that such an understanding will be lost if the focus rests on the spatial configurations of immersive theatre environments alone, rather than on how audiences are asked to encounter an environment. Immersive theatre describes a mode of encounter, rather than a particular theatre practice or spatial configuration; it is a term that can be applied to a range of practices in a range of contexts, so long as an audience engages with an environment that prompts the perception of immersion's cues.

Perhaps surprisingly, errant immersion goes some way toward demonstrating the constitutive role played by audiences in the formation of an immersive theatre aesthetic. While errant immersion implies an accidentally insubordinate audience, in another sense it implies an ideal audience who subscribes to a framework for audience engagement not just well, but too well. The errantly immersed spectator invests in performance more than what is expected of them, on the same terms that form the very least that is required for a sense of immersion to be achieved - in other words, committing not just to a physical 
immersion in a deliberately crafted space, but to a personal investment in what is perceived to be part of an immersive world. A sense of immersion relies on the creatively productive perception of audiences in dynamic relation with a perceived immersive environment that may well be ambiguously defined, or mistakenly apprehended. This is a condition that errant immersion clarifies, without creating.

\section{Works cited}

Alston, Adam. "Audience Participation and Neoliberal Value: Risk, Agency and Responsibility in Immersive Theatre". Performance Research 18.2 (June 2013): 128-38. Print.

Alston, Adam. Beyond Immersive Theatre: Aesthetics, Politics and Productive Participation. London and New York: Palgrave Macmillan, 2016. Print.

Bailes, Sara Jane. Performance Theatre and the Poetics of Failure: Forced Entertainment, Goat Island, Elevator Repair Service. London: Routledge, 2011. Print.

Blažević, Marin. “Intro 2: Dramaturgy of Shift(s)(ing)”. Performance Research 15.2 (2010): 5-11. Print.

Blažević, Marin and Lada Čale Feldman. "Introduction". MISperformance - Essays in Shifting Perspectives. Eds. Marin Blažević and Lada Čale Feldman. Ljubljana: Maska, Institute for Publishing, Production and Education, 2014. 11-28. Print.

Brewis, Becky. "Behind the Scenes: Coney Playday". A Younger Theatre. 22 May 2012. Web. <http://www.ayoungertheatre.com/behind-the-scenes-coney-playday/>. (Date of access: 1 July 2015).

Calleja, Gordon. In-Game: From Immersion to Incorporation. Cambridge: MIT, 2011. Print.

Dinesh, Nandita. "Delusions of Singularity: Aesthetics, Discomfort and Bewilderment in Kashmir". RiDE 20.1 (2015): 62-73. Print.

Feldman, Lada Čale. “Intro 1: PSi Mis-Performing Papers”. Performance Research 15.2 (2010): 1-5. Print.

Ferdman, Bertie. “Urban Dramaturgy: The Global Art Project of JR”. PA/ 34.3 (Sept. 2012): 12-26. Print.

Ferdman, Bertie. “Off the Grid: New York City Landmark Performance”. PA/ 37.2 (May 2015): 13-29. Print.

Frieze, James. "Beyond the Zero-sum Game: Participation and the Optics of Voting”. Contemporary Theatre Review 25.2 (2015): 216-29. Print.

Gardner, Lyn. "Faust”. The Guardian 19 Oct. 2006. Web. <http://www.theguardian.com/stage/ 2006/oct/19/theatre>. (Date of access: 1 July 2015).

Kershaw, Baz. The Radical in Performance: Between Brecht and Baudrillard. London: Routledge, 1999. Print.

Kroeber, Gavin. “The Event Landscape: The Contemporary Encounter of Art and the City”. PA/ 37.2 (May 2015): 30-41. Print.

Machon, Josephine. Immersive Theatres: Intimacy and Immediacy in Contemporary Performance. Basingstoke and New York: Palgrave Macmillan, 2013. Print.

McKenzie, Jon. "Virtual Reality: Performance, Immersion, and the Thaw”. TDR 38.4 (Winter 1994): 83-106. Print. 
Nield, Sophie. “The Rise of the Character Named Spectator”. Contemporary Theatre Review. 18.4 (2008): 531-44. Print.

Occupy London. “Initial Statement”. 16 October 2011. Web. <http://occupylondon.org.uk/about/ statements/initial-statement/>. (Date of access: 7 May 2015).

Rancière, Jacques. The Emancipated Spectator. Trans. Gregory Elliot. London: Verso, 2009. Print. Ridout, Nicholas. Stage Fright, Animals, and Other Theatrical Problems. Cambridge: Cambridge UP, 2006. Print.

Ridout, Nicholas. “Mis-spectatorship, or, 'Redistributing the Sensible”. Archaeologies of Presence. Eds. Gabriella Giannachi, Nick Kaye, and Michael Shanks. London and New York: Routledge, 2012. 172-82. Print.

Sharps, Tristan. Personal interview. Somerset House, London, 28 May 2015.

Werry, Margaret and Bryan Schmidt. "Immersion and the Spectator". Theatre Journal 66.3 (2014): 467-79. Print.

White, Gareth. “On Immersive Theatre”. Theatre Research International 37.3 (Oct 2012): 221-35. Print.

Zaointz, Keren. "Narcissistic Spectatorship in Immersive and One-on-One Performance”. Theatre Journal 66 (2014): 405-25. Print.

\section{Bionote}

Adam Alston

University of Surrey, a.alston@surrey.ac.uk

Adam Alston is a Lecturer in Theatre and Performance Studies specialising in immersive and participatory theatre practices, with a particular focus on the aesthetics and politics of audience engagement. More recently he has been addressing notions of labour, secrecy and error in contemporary theatre, and the histories, aesthetics and phenomenology of partial and complete darkness in avant-garde and contemporary theatre and performance. His first monograph, Beyond Immersive Theatre: Aesthetics, Politics and Productive Participation, was published with Palgrave Macmillan in early 2016, and he is currently working on a co-edited collection with Martin Welton (QMUL), contracted with Methuen, titled Theatre in the Dark: Shadow, Gloom and Blackout in Contemporary Theatre. He is part of the editorial team for Contemporary Theatre Review's online Interventions, and works as a Creative Associate with the devised, science-led theatre company Curious Directive. 